COGNitive Studies | Études COGNitives, 12 SOW Publishing House, Warsaw 2012

\author{
VIOLETTA KOSESKA-TOSZEWA ${ }^{1, A}$, JOANNA SATOŁA-STAŚSKOWIAK ${ }^{1, B}$, \\ MAKSIM DUSZKIN ${ }^{1, C}$ \\ ${ }^{1}$ Institute of Slavic Studies, Polish Academy of Sciences, Warsaw, Poland \\ ${ }^{A}$ amaz@inetia.pl , $B$ joannasat@op.pl , ${ }^{C}$ demaksid@gmail.com
}

\title{
POLISH-BULGARIAN-RUSSIAN, BULGARIAN-POLISH-RUSSIAN OR RUSSIAN-BULGARIAN-POLISH DICTIONARY?
}

\begin{abstract}
The trilingual dictionary (M. Duszkin, V. Koseska, J.Satoła and A. Tzoneva) is being elaborated based on a working Polish-Bulgarian-Russian electronic parallel corpus authored by Maksim Duszkin, Violetta Koseska-Toszewa and Joanna Satoła-Staśkowiak, and works by A. Tzoneva. It is the first corpus comparing languages belonging to three different Slavic language groups: western, southern and eastern. Works on the dictionary are based on Gramatyka konfrontatywna butgarsko-polska (Bulgarian-Polish confrontative grammar) and the proposed there semantic-oriented interlanguage. Two types of classifiers have been introduced into the dictionary: classic and semantic. The trilingual dictionary will present a consistent and homogeneous set of facts of grammar and semantics. The Authors point out that in a traditional dictionary it is not clear for example whether aspect should be understood as imperfective / perfective form of a verb or as its meaning. Therefore in the dictionary forms and meaning are separated in a regular way. Imperfective verb form has two meanings: state and configuration of states and events culminating in state. Also perfective verb form has two meanings: event and configuration of states and events culminating in event. These meanings are described by the semantic classifiers, respectively, state and event, state1 and event1. The way of describing language units, mentioned in the article, gives a possibility to present language material (Polish, Bulgarian, Russian) in any required order, hence the article's title.

Keywords: trilingual dictionary, form, meaning, semantic classifiers, state, event, classic classifiers, intransitive, transitive, temporal-aspect relation.
\end{abstract}

The dictionary we want to present here concerns three languages covering the southern, eastern and western groups of Slavic languages. Its authors are Maksim Duszkin, Violetta Koseska-Toszewa and Joanna Satoła-Staśkowiak on the Polish side, and Anastasja Tzoneva on the Bulgarian side. We are planning to publish it as a book consisting of six issues. The dictionary is being elaborated based on 
a working electronic parallel corpus authored by Maksim Duszkin, Violetta Koseska-Toszewa and Joanna Satoła-Staśkowiak, and works by A. Tzoneva.

Classic and semantic classifiers in the Dictionary. We intend to elaborate the entries in all the languages to enable easy establishment of a database for future dictionaries, also electronic ones. This means, among others, that entries should contain meanings and classifiers in each of the languages, in opposition to traditional bi- and tri-lingual dictionaries, which provide the meanings and classifiers in one language only.

Our requirement causes a lot of problems. As it is well known that there are significant differences in classification of the parts of speech in different linguistic schools, therefore unification of classifiers for two and three languages is not an easy task. An additional challenge faced by the Team in the Dictionary project is introduction of three classifier types. The first and the second group will consist of traditional classifiers, which we call classic here. Classic classifiers include separate parts of speech: adjective, verb, noun, together with their morphological characteristic adopted in the literature, e.g. gender, number, etc. Classic classifiers like ksiaz. (lit.), pot. (coll.) are also taken into consideration. The dictionary will also employ syntactic classifiers with the transitiv and intransitiv indicating transitivity and intransitivity of the verbum, respectively. By a transitive verb we will understand one that can be followed by a direct object in a sentence. In Polish and Russian sentences, a transitive verb is followed by a nomen in the accusative case. However, intransitivity excludes the above possibility. Intransitive verbs cannot be followed by a direct object, and in Polish the verbum form can be followed by all case forms except the accusative case. As our dictionary is not a valence dictionary, the above definition should satisfy our recipient. Examples:

(Pol.) strajkować vi., state, intransitiv - (Bulg.) стачкувам vi., state, intransitiv - (Russ.) бастовать vi., state, intransitiv

(Pol.) zastrajkować vp., event, intransitiv - (Bulg.) започна (обявя) стачка vp., event, intransitiv - (Russ.) забастовать vp., event, intransitiv

(Pol.) rozgraniczać vi. state, transitiv - (Bulg.) разграничавам vi. state, transitiv - (Russ.) разграничивать vi. state, transitiv

(Pol.) rozgraniczyć vp. event, transitiv - (Bulg.) разгранича vp. event, transitiv - (Russ.) разграничить vp. event, transitiv

The next group of classifiers will be semantic classifiers, which have been isolated during the many years of work on a semantic contrastive study little known in Poland, but first such in the world. It was conducted in the work called Gramatyka konfrontatywna języka polskiego $i$ butgarskiego z semantycznym językiem-pośrednikiem [Contrastive Grammar of Polish and Bulgarian with Semantic Interlanguage] (Koseska-Toszewa 2006), consisting of 12 monographs. We realize that semantic classifiers are not easy to isolate, and in order to do it, a consistent separation of the form and the meanings is necessary. For example, are the imperfective and perfective aspects used as classifiers in commonly known dictionaries forms of a verb, or its meanings? 
Let us return to the question about the form and the meaning. The issue is fundamental, and still difficult. This can be seen in traditional linguistics, where still very often the form is not distinguished from its meaning. As we know, a language form is a unit which plays a specific function in the language, e.g. semantic or syntactical one. The actual function of a form is established based on its use (occurrence), that is, its relations with the meanings of other forms in speech and text. The meaning of a form is the value of its function. We will show this issue on the example of the semantic categories of time and aspect elaborated in the Contrastive Grammar (Koseska-Toszewa 2006). Regardless of whether aspect is a grammatical, morphological or semantic category, it cannot be disregarded during the analysis of temporal relations, especially in Bulgarian. The discussions on that subject between Bulgarian linguists representing the so-called temporal school with representatives of the so-called aspectual school are well known. The works classified to the temporal school are those by L. Andrejchin, V. Stankov, M. Dejanova, and to the aspectual school - those by Ju. Maslov, E. Demina, S. Ivanchev. As we know, languages possessing aspect are characterized by a small number of tenses, like north-Slavic languages, while languages devoid of aspect have a higher number of tenses (like Latin or French). As a result, South-Slavic languages could be expected to exhibit two different tendencies: the first towards reducing the number of tenses (like in Serbian and Croatian), and the second involving disappearance (or insufficient development) of aspect while maintaining a large number of tenses. This tendency was claimed to exist e.g. in Bulgarian. However, in the eastern group of South-Slavic languages the aspect category exists, and yet the number of tenses does not decrease in them. From the typological viewpoint, South-Slavic languages, and in particular their eastern group, constitute a transitory stage between Greek and Latin on the one hand (a large number of tenses, absence of the aspect category) and North-Slavic languages (the aspect category, a small number of tenses) on the other hand. Hence the problems of temporal relations in southern Slavic lands are especially important both for clarifying the Slavic aspect category and for the semantics of tenses in Slavic languages.

In view of the above, it is worth while to remind the hypothesis by S. Ivanchev (1971:129), in whose opinion there is a genetic connection between the imperfective aspect and imperfectum. He does not examine the aorist : imperfectum relation as an either temporal or aspectual one, but as a joint temporally-aspectual relation. In Serbian, the imperfectum form could only be built for imperfective verbs and had a clearly aspectual character, in opposition to the Serbian aorist form, which could be perfect, but also imperfect (though very rarely) (Vuković 1967: 276-313.) Linguistic facts from old Bulgarian sources confirm that the ratio of imperfectum forms of perfective verbs to imperfectum forms of imperfective verbs is 1:99 (Dostál 1954). On that basis, some scholars consider the bi-aspectual nature of aorist and imperfectum forms as an archaic state of things (Koschmieder 1963: 19). However, in the Bułgarian and Macedonian area this is a live phenomenon, which is not transient at the present stage of language development.

The connections between aspect and temporality in South Slavic languages (except for Slovenian) confirm Kuryłowicz's thesis about the semantic charac- 
ter of aspect (Feleszko, Koseska-Toszewa, Sawicka 1974: 183-187.), (Bogusławski 2003), (Karolak 2008). In turn, Gołąb, Heinz and Polański, when examining the notions of aspect and its strict connections with the category of time, propose a chart which fully explains the differences in meaning that distinguish both the categories. The chart reduces to the fact the exponents of time position a given activity with respect to the speech state (the so-called moment of speaking), while exponents of aspect position the same activity with respect to the point that represent the moment of ending the action, regardless of the speech state, see (Gołąb, Heinz, Polański 1968), (Koseska-Toszewa 1974: 213-226).

Here we understand the semantic category of time like in the Polish-Bulgarian Contrastive Grammar - as a category that orders states and events with respect to the speech state using the precedence-succession relation (Koseska-Toszewa 2006). For the basic notions - states and events - as elements of aspectuality and temporality, see (Mazurkiewicz 1986).

As we have already mentioned, our dictionary entries should obligatorily distinguish between the language form and its content. The semantic classifiers concerning aspect and time will be the notions of event and state presented in the dictionary. An Event is either 1. an event, or 2. a configuration of states and events ending with an event. These are two contents of perfect forms of verbs. In turn, a State is an abbreviation representing either 1. a state, or 2. a configuration of states and events ending with a state. These two contents are possessed by imperfect forms of verbs.

Here the notions of states, events and their configurations are understood as in the network-based description of time and aspect. Namely, we assume that an event has no duration (it begins, ends or breaks states), while a state lasts, and is begun or ended with an event. For more details on the Petri net theory and its application to natural languge, see (Mazurkiewicz 1986), (Koseska-Toszewa, Mazurkiewicz 1988), (Koseska-Toszewa 2006), (Koseska-Toszewa, Mazurkiewicz 2010). We assume that if a verb form is denoted by "ndk", then its meanings will be presented as state 1 . - a state or state 2 - a combination of states and events ending with a state, while a verb form denoted by „ $d k$ " will have the semantic classifier event 1., i.e. an event, or event 2. - a combination of states and events ending with an event. Meanings 1 and 2 for an event and meanings 1 and 2 for a state can be clearly shown in the temporally-aspectual relation, i.e. when the verbal form expresses a specific tense. This is why the infinitive form, which is "tense-free", will be accompanied by state and event abbreviations only.

We will use the example of the praesens form (present tense form) to show what are its basic temporal meanings in Bulgarian and Polish, as well as in Russian. The above form does not represent the present tense only in any of these languages, see: (Grochowski 1972), (Koseska-Toszewa 1972). The present tense form has the following meanings:

1. The present tense of a verbal form with a state 1 classifier, expressing a state.

Bulg. Анета спи в моята стая.,

Pol. Aneta śpi w moim pokoju.

Russ. Анета спит в моей комнате. 
2. The future tense of a verbal form with a modal meaning expressing possibility (rather than truth or falsity) is outside this classification.

Bulg. Утре идвам в два, а не в три часа.

Pol. Jutro przychodzę o drugiej, nie o trzeciej.

Russ. Я завтра прихожу в два, а не в три часа.

3. The past tense of a verbal form expressing a configuration of events and states ending with a state, has the state 2 classifier:

Bulg. И чак тогава той разбира своите грешки.

Pol. I dopiero wtedy on rozumie swoje błędy

Russ. И только тогда он понимает свои ошибки.

4. Habituality - the verbal form expresses configuration of states and events without any information about the ending state, and is outside this classification. A discussion is rightly pending whether a habitual meaning is a tense.

Bulg. Той всеки ден са разхожда поне един час.

Pol. On codziennie spaceruje przynajmniej jedną godzinę.

Russ. Каждый день он гуляет хотя бы один час.

We should add that sentences (1) are in the present tense; they are in the indicative form, and hence have the value of either truth or falsity. From this viewpoint, sentences (1) differ e.g. from sentences (2) in the future tense, which do not have the value of either truth or falsity, i.e. are not in the indicative form. Instead, they have a third value - possibility, which is a modal value. Are the sentences: Jan ponoć teraz jest na spacerze. Ян бил сега на разходка. / Ян уж е сега на разходка. Ян сейчас будто бы на прогулке. actual present tense sentences, or just sentences with a present tense form? Certainly, they are not sentences with the value either truth or falsity, and hence they cannot be sentences expressing present tense. This is proven, among others, by Bulgarian, where the $б u \Omega$ form is a signal of an imperceptive modality rather than present tense, see Toü сега е на разходка., where we have present tense. Sentences with various types of a possibility modality, not only the imperceptive one like above, often occur with the praesens form. However, they also have a third value - possibility, so during the speech state we do not know if the state or the combination of a state and events exist or not. In such a case, we cannot speak about the present tense, but only about a present tense form, see e.g.: On jakoby jest złodziejem. / Toŭ мaŭ е крадец. / Той бил крадец. / Он якоби вор. The interpretation of the above sentences as present tense ones is a good example of not distinguishing between a verbal form and its temporal function. Defining present tense more precisely, it is worth stressing that the present, and hence what is happening now according to the carrier of the speech state, should be understood as either a state concurrent with the speech state or as a combination of the event beginning or ending a state concurrent with the speech state. Very roughly speaking, we can also understand it solely as a state concurrent with the speech state. However, Bulgarian grammars commonly use formulations of the type: „this a metaphorical meaning of present tense", though the present tense is the meaning of the present tense form (Stankov 
1969). Such formulations amount to speaking about another meaning of some meaning - in other words, to a tautology.

It should be stressed that Bulgarian, where we meet aorist forms not only of perfective verbs, but also of imperfective verbs, and imperfectum forms not only of imperfective verbs, but also of perfective verbs, allows us to notice temporallyaspectual meanings rendered in other Slavic languages not only using verb forms, but also through other lexical means. This requires distinguishing between the state 1 and state 2 classifiers, and event 1 and event 2 classifiers. In turn, this distinction shows that temporally-aspectual relationships constitute a semantic whole, which consists of the meanings of aspect and time. However, in the dictionary we only leave the state and event classifiers at the entries with infinitive forms, since state 1 and state 2, and event 1 and event 2, can only be distinguished when the verbal form expresses tense, i.e. when it is not an infinitive. Hence the state 1 and state 2, as well as event 1 and event 2 classifiers, will only appear with perfective and imperfective verbs expressing temporal meanings in Bulgarian, Polish and Russian texts.

In the dictionary, only entries in the first language are ordered alphabetically. If that language is Polish, then only Polish entries are ordered alphabetically, while the entries given in the Bulgarian and Russian sections are not ordered alphabetically. It should be emphasized that Bulgarian and Russian entries are language forms, just like Polish entries. The meanings of Bulgarian and Russian entries correspond to the meanings of Polish entries. From the working procedure viewpoint, this looks as follows. We choose an entry in the first language, e.g. in Polish, and determine its main meaning. Then we look for entries in the second and third language that have the same meaning. Since the initial form of the entry may have a different number of meanings in each language, we order them, marking absence of a meaning in some of the languages, if such occurs. It is worth emphasizing that we base determination of semantic classifiers on the semantic interlanguage developed in the Bulgarian-Polish Contrastive Grammar, concerning the semantics of time and aspect, see (Koseska-Toszewa 2006), (Koseska-Toszewa, Mazurkiewicz 2010). We have begun our work with distinguishing between the forms of aspect and time in all the three language and the appropriate meanings of those forms. This choice can be explained by the fact that only in Slavic languages the aspect category has a formal paradigm.

The classifiers used for marking the entries are the same in all the three languages. Graphically, the dictionary will represent a three-column table. The first column of the table will describe, for example, Polish material, the second - Bulgarian, and the third - Russian one. Each row of the table will contain a separate tri-lingual entry article, consisting of the material from the three columns of the given table row.

Samples of a few entries created in line with the above assumptions are given in the Table 1. 
Table 1.

\begin{tabular}{|c|c|c|}
\hline babc|ia, -i, -ie $n . f$ & баб|а, -и $n . f$. & бабушк|а, -и, -и $n . f$. \\
\hline $\begin{array}{l}\text { 1. 'father's or mother's } \\
\text { mother': }\end{array}$ & $\begin{array}{l}\text { 1. 'father's or mother's } \\
\text { mother': }\end{array}$ & $\begin{array}{l}\text { 1. 'father's or mother's } \\
\text { mother': }\end{array}$ \\
\hline $\begin{array}{l}\text { Latem } w \text { ogrodzie naszej } \\
\text { babci kwitna kwiaty. }\end{array}$ & $\begin{array}{l}\text { През лятото в градина- } \\
\text { та на нашата баба избб- } \\
\text { тят ияета. }\end{array}$ & $\begin{array}{l}\text { Летом в саду у нашей } \\
\text { бабушки цветут цветы. }\end{array}$ \\
\hline 2. 'old woman' & 2. 'old woman' & 2. 'old woman' \\
\hline $\begin{array}{l}\text { Na ławce siadły dwie bab- } \\
\text { cie zmęczone spacerem. }\end{array}$ & $\begin{array}{l}\text { На пейката седнаха две } \\
\text { баби уморени от разход- } \\
\text { ката. }\end{array}$ & $\begin{array}{l}\text { На скамейке уселись две } \\
\text { бабушки, уставшие по- } \\
\text { сле прогулки }\end{array}$ \\
\hline
\end{tabular}

\begin{tabular}{|l|l|l|}
\hline $\begin{array}{l}\text { siatk|a, -i, -i (na zakupy) } \\
n . f .\end{array}$ & $\begin{array}{l}\text { мреж|a, -и } n . f . \quad \text { (за по- } \\
\text { купки) }\end{array}$ & авоськ|а, -и, -и $n . f$. \\
'a kind of shopping bag' & 'a kind of shopping bag' & 'a kind of shopping bag' \\
$\begin{array}{l}\text { Kupiłam nowa siatke na } \\
\text { zakupy. }\end{array}$ & $\begin{array}{l}\text { Купих нова мрежа за } \\
\text { покупки. }\end{array}$ & Я купила новую авосъкy. \\
\hline
\end{tabular}

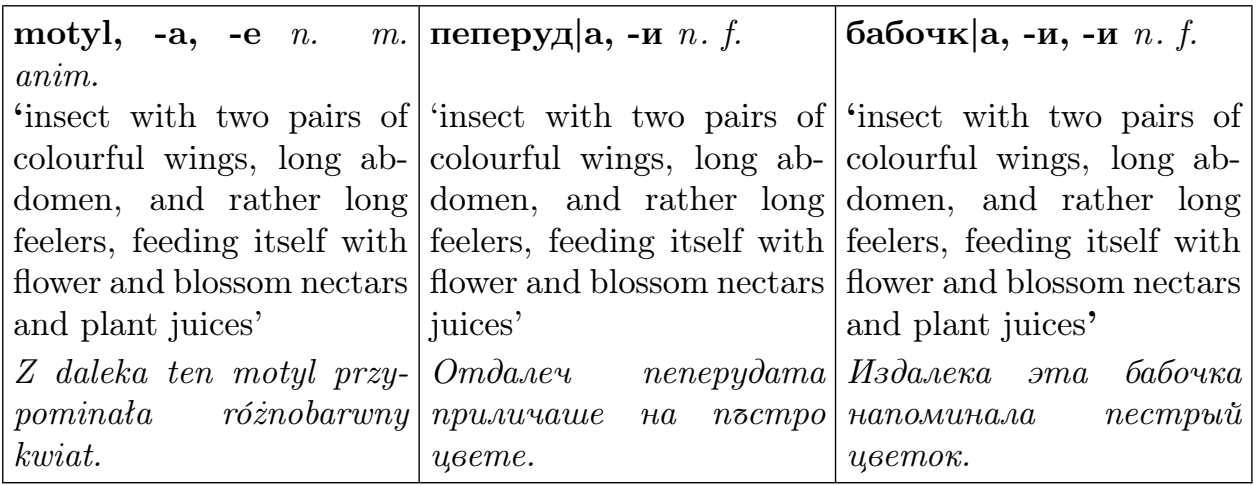

strajk|ować, -uję, -ujesz vi., state, intransitiv 'participate in a strike (industrial action)'

Kolejarze znów chca strajkować

\begin{tabular}{|c|c|}
\hline $\begin{array}{l}\text { да стачкува|м, -аш, -а } \\
\text { vi., state, intransitiv } \\
\text { 'participate in a strike (in- } \\
\text { dustrial action)' }\end{array}$ & $\begin{array}{l}\text { баст|овать, -ую, -уешь } \\
\text { vi., state, intransitiv } \\
\text { 'participate in a strike (in- } \\
\text { dustrial action)' }\end{array}$ \\
\hline $\begin{array}{l}\text { Келезничарите искат } \\
\text { пново да стачкуват. }\end{array}$ & $\begin{array}{l}\text { Железнодорожники } \\
\text { вновь хотят бастовать }\end{array}$ \\
\hline
\end{tabular}

да стачкува|м, -аш, -а баст|овать, -ую, -уешь 'participate in a strike (in- 'participate in a strike (industrial action)' dustrial action)'

отново да стачкуват. вновь хотят бастовать 


\begin{tabular}{|c|c|c|}
\hline $\begin{array}{l}\text { zastrajk|ować, -uję, -u- } \\
\text { jesz vp., event, intransitiv }\end{array}$ & $\begin{array}{l}\text { да започн|а, -еш, -е } \\
\text { (обявя) стачка vp., } \\
\text { event, intransitiv }\end{array}$ & $\begin{array}{l}\text { забаст|овать, -ую, -у- } \\
\text { ешь vp., event, intransi- } \\
\text { tiv }\end{array}$ \\
\hline $\begin{array}{l}\text { 'announce a strike (indus- } \\
\text { trial action)' }\end{array}$ & $\begin{array}{l}\text { 'announce a strike (indus- } \\
\text { trial action)' }\end{array}$ & $\begin{array}{l}\text { 'announce a strike (indus- } \\
\text { trial action)' }\end{array}$ \\
\hline $\begin{array}{l}\text { Robotnicy } \\
\text { strajk. }\end{array}$ & $\begin{array}{l}\text { Работниците започнаха } \\
\text { стачка. }\end{array}$ & Рабочие начали страйк \\
\hline
\end{tabular}

\begin{tabular}{|c|c|c|}
\hline $\begin{array}{l}\text { artykuł, } \mathbf{- u ,}-\mathbf{y} n . m . i n- \\
\text { anim. }\end{array}$ & стати|я, -и, $n$. & стать|я, -и, и $n$. \\
\hline $\begin{array}{l}\text { 1. 'separate publication in } \\
\text { a newspaper or a journal' }\end{array}$ & $\begin{array}{l}\text { 1. 'separate publication in } \\
\text { a newspaper or a journal' }\end{array}$ & $\begin{array}{l}\text { 1. 'separate publication in } \\
\text { a newspaper or a journal' }\end{array}$ \\
\hline kontrowersyjny artykut & оспорвана статия & спорная статъя \\
\hline 2. 'traded object' & $\begin{array}{l}2 . \text { - no meaning } \\
(\text { see сток|а, -и } n . f ., \text { ap- } \\
\text { тикул, -и } n . m .)\end{array}$ & $\begin{array}{l}\text { 2. - no meaning } \\
\text { (see товар } n . m .)\end{array}$ \\
\hline $\begin{array}{lr}\text { artykuły } & \text { gospodarstwa } \\
\text { domowego; } & \text { artykuły } \\
\text { spożywcze } & \end{array}$ & & \\
\hline $\begin{array}{l}3 . \text { spec. 'section (item) } \\
\text { in a legal document, part } \\
\text { of a document represent- } \\
\text { ing a separate whole from } \\
\text { the viewpoint of contents } \\
\text { (legal term)' }\end{array}$ & $\begin{array}{l}\text { 3. - no meaning } \\
\text { (see член } n . \quad m ., \text { пара- } \\
\text { граф } n . m .)\end{array}$ & $\begin{array}{l}\text { 3. spec. 'section (item) } \\
\text { in a legal document, part } \\
\text { of a document represent- } \\
\text { ing a separate whole from } \\
\text { the viewpoint of contents } \\
\text { (legal term)' }\end{array}$ \\
\hline $\begin{array}{l}\text { artykut 123 Kodeksu } \\
\text { Karnego }\end{array}$ & & $\begin{array}{l}\text { статъя 123 Уголовного } \\
\text { кодекса }\end{array}$ \\
\hline $\begin{array}{l}\text { 4. spec. 'entry article' } \\
\text { (term referring to a short } \\
\text { text in a dictionary) }\end{array}$ & $\begin{array}{l}\text { 4. spec. 'entry article' } \\
\text { (term referring to a short } \\
\text { text in a dictionary) }\end{array}$ & $\begin{array}{l}\text { 4. spec. 'entry article' } \\
\text { (term referring to a short } \\
\text { text in a dictionary) }\end{array}$ \\
\hline artykuł hastowy & речникова статия & словарная статья \\
\hline
\end{tabular}

Both each Polish entry and its Russian and Bulgarian analogues are elaborated in the dictionary in as much detail as possible, without any bias towards information on any of these three languages.

Each of the languages in our dictionary is elaborated in the same way - each language is assigned the appropriate classic and semantic classifiers. As a result, it is of no consequence which language appears in the first column of the dictionary table.

Here is another example of a trilingual dictionary, where the starting point is not Polish but Bulgarian: 


\begin{tabular}{|c|c|c|}
\hline Bulgarian & Russian & Polish \\
\hline авари|я, -и $n . f$. & авари|я, -и, -и $n . f$. & awari|a, -i, -e $n . f$. \\
\hline $\begin{array}{l}\text { 1. 'damage to a machine } \\
\text { or other technical device' }\end{array}$ & $\begin{array}{l}\text { 1. 'damage to a machine } \\
\text { or other technical device' }\end{array}$ & $\begin{array}{l}\text { 1. 'damage to a machine } \\
\text { or other technical device' }\end{array}$ \\
\hline $\begin{array}{l}\text { тежка авария (на бен- } \\
\text { зиностани,я) }\end{array}$ & $\begin{array}{l}\text { крупная авария (на газо- } \\
\text { вой станции) }\end{array}$ & $\begin{array}{l}\text { cięzka awaria (na stacji } \\
\text { benzynowej) }\end{array}$ \\
\hline 2. 'accident' & 2. 'accident' & $\begin{array}{l}\text { - no meaning } \\
\text { (see wypadek wypadek } \\
\text { samochodowy) }\end{array}$ \\
\hline авария на кола & автомобильная авария & \\
\hline
\end{tabular}

The starting point can also be Russian, see e.g.:

\begin{tabular}{|c|c|c|}
\hline Russian & Bulgarian & Polish \\
\hline гла|дить, -жу, -дишь & глад|я, -иш, -и vi. state, & pras|ować, -uję, ujesz \\
\hline $\begin{array}{l}\text { 1. 'smooth down fabric } \\
\text { using a hot iron, an iron- } \\
\text { ing device, etc.' }\end{array}$ & $\begin{array}{l}\text { 1. 'smooth down fabric } \\
\text { using a hot iron, an iron- } \\
\text { ing device.' }\end{array}$ & $\begin{array}{l}\text { 1. 'smooth down fabric } \\
\text { using a hot iron, an iron- } \\
\text { ing device.' }\end{array}$ \\
\hline $\begin{array}{l}\text { гладить костюм утю- } \\
\text { гом }\end{array}$ & гладя костюм с ютия & $\begin{array}{l}\text { prasować garnitur żelaz- } \\
\text { kiem }\end{array}$ \\
\hline $\begin{array}{l}\text { 2. 'pass one's hand over } \\
\text { something in a delicate } \\
\text { way, usually caressing it' }\end{array}$ & $\begin{array}{l}\text { 2. 'pass one's hand over } \\
\text { something in a delicate } \\
\text { way, usually caressing it' }\end{array}$ & $\begin{array}{l}\text { 2. no meaning } \\
\text { (see gładzić, głaskać) }\end{array}$ \\
\hline гладить рукой по щеке & $\begin{array}{l}\text { гладя с рбка по бузата } \\
(\text { sее милвам) }\end{array}$ & \\
\hline
\end{tabular}

\begin{tabular}{|c|c|c|}
\hline Russian & Bulgarian & Polish \\
\hline $\begin{array}{l}\text { покупа|ть, -ю, -ешь vi, } \\
\text { state, transitiv }\end{array}$ & $\begin{array}{l}\text { купув } \mid \text { ам, -аш, -а vi., } \\
\text { state, transitiv }\end{array}$ & 3 \\
\hline $\begin{array}{l}\text { 1. 'purchase something at } \\
\text { a certain price, for a cer- } \\
\text { tain amount of money' }\end{array}$ & $\begin{array}{l}\text { 1. 'purchase something at } \\
\text { a certain price, for a cer- } \\
\text { tain amount of money' }\end{array}$ & $\begin{array}{l}\text { 1. 'purchase something at } \\
\text { a certain price, for a cer- } \\
\text { tain amount of money' }\end{array}$ \\
\hline покупать клубнику & да купувам ягоди & kupować truskawki \\
\hline $\begin{array}{l}\text { 2. met. (кого-либо) 'se- } \\
\text { cure somebody's support, } \\
\text { favour for oneself by giving } \\
\text { them money, gifts, a bribe' }\end{array}$ & $\begin{array}{l}\text { met. 'secure somebody's } \\
\text { support, favour for oneself } \\
\text { by giving them money, gi- } \\
\text { fts, a bribe' }\end{array}$ & $\begin{array}{l}\text { 2. - no meaning } \\
\text { (see przekupywać) }\end{array}$ \\
\hline покупать чиновника & да купувам чиновника & \\
\hline
\end{tabular}




\begin{tabular}{|c|c|c|}
\hline Russian & Bulgarian & Polish \\
\hline $\begin{array}{l}\text { проведа|ть, -ю, -ешь } \\
\text { vp, event, transitiv } \\
\text { 1. 'pay somebody a visit', } \\
\text { навестить больного } \\
\text { 2. 'learn about something } \\
\text { (most often from rumours, } \\
\text { accidentally)' } \\
\text { проведать о тайньх } \\
\text { планах, проведать о } \\
\text { приезде писателя }\end{array}$ & $\begin{array}{l}\text { навест|я, -иш, -и vp. } \\
\text { event, transitiv } \\
\text { 1. 'pay somebody a visit' } \\
\text { навестя болен } \\
\text { 2. - nо meaning } \\
\text { (sеe узная, разузная, } \\
\text { науча) }\end{array}$ & $\begin{array}{l}\text { odwiedz|ić, -ę, -isz vp. } \\
\text { event, transitiv } \\
\text { 1. 'pay somebody a visit' } \\
\text { odwiedzić chorego } \\
\text { 2. - no meaning } \\
\text { (see dowiedzieć się) }\end{array}$ \\
\hline
\end{tabular}

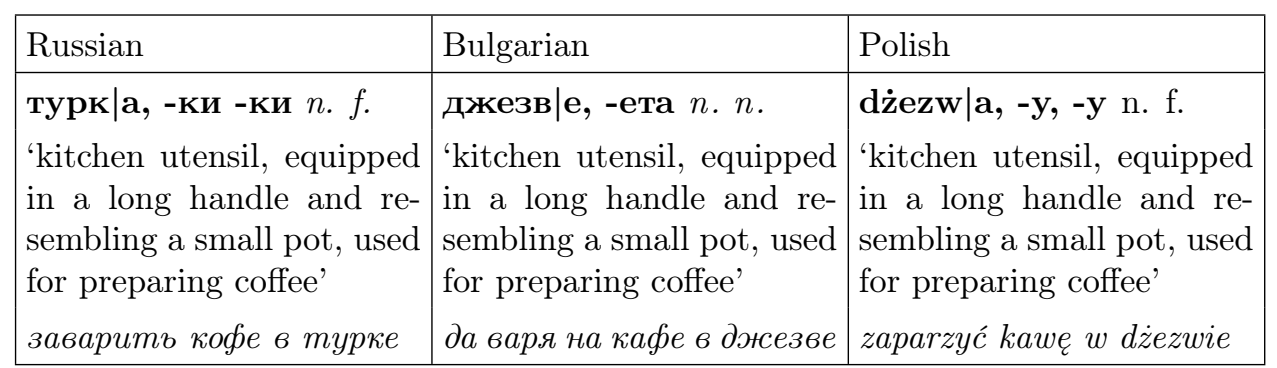

The dictionary we are developing is positioned within the framework of contemporary research on semantics and on contrasting languages. It will not be a collection of finished conclusions regarding differences and similarities between lexical units of various languages, but a collection of semantic and grammatical facts indicating similarities and differences in the studied languages, consistently and uniformly registered and COMPARED WITH EACH OTHER. We hope that these facts can be used as a foundation for further studies on Polish, Bulgarian and Russian and their contemporary development.

\section{References}

Bogusławski 2003: A. Bogusławski, Aspekt i negacja, Warszawa.

Dimitrowa, Koseska, Satoła 2012: L. Dimitrowa, V. Koseska-Toszewa, J. Satoła-Staśkowiak, About Neologisms in Bilingual Digital Dictionaries (on example of BulgarianPolish Dictionary), (In this volume).

Dostál 1954: A. Dostál, Studie o vidovém systému v staroslověnštině, Praha.

Feleszko, Koseska, Sawicka 1974: K. Feleszko, V. Koseska-Toszewa, I. Sawicka, Zwiazki aspektu z temporalnościa w językach południowosłowiańskich, SFPS XIV: 183-187.

Gołąb, Heinz, Polański 1968: Z. Gołąb, A. Heinz, K. Polański, Stownik terminologii językoznawczej, Kraków.

Grochowski 1972: M. Grochowski, Znaczenia polskiego czasownika: aktualne, potencjalne, uniwersalne, w świetle kategorialnego znaczenia form „czasu teraźniejszego”, Studia semiotyczne, vol. III, Wrocław. 
Isachenko 1966: A. Isachenko, Grammaticheskij stroj russkogo jazyka v sopostavlenii s slovackim, Morfologija, vol. I, Bratislava, page 26.

Ivanchev 1971: S. Ivanchev, Problemi na aspektualnostta v slavjanskite ezici, Sofija.

Karolak 2008: S. Karolak, Semantyczna kategoria aspektu, GKBP, vol. 8, Warszawa.

Koschmieder 1963: E. Koschmieder, Aspect und Zeit, Opera Slavica IV, Göttingen.

Koseska-Toszewa 1972 V. Koseska-Toszewa, System temporalny pótnocno-zachodniej gwary bułgarskiej na tle języka literackiego, SFPS XII, pages 233-245.

Koseska-Toszewa 1974: V. Koseska-Toszewa, Z problematyki temporalno-aspektowej w języku bułgarskim (relacja imperfectum : aoryst), SFPS XIV, pages 213-226.

Koseska-Toszewa 1982: V. Koseska-Toszewa, Semantyczne aspekty kategorii określoności / nieokreśloności (na materiale języka bułgarskiego, polskiego i rosyjskiego), Wrocław, Ossolineum.

Koseska-Toszewa 2006: V. Koseska-Toszewa, Gramatyka konfrontatywna bułgarskopolska, t.7, Semantyczna kategoria czasu, SOW, Warszawa.

Koseska-Toszewa, Mazurkiewicz 1988: V. Koseska-Toszewa, A. Mazurkiewicz, Net Representation of Sentences in Natural Languages. In Lecture Notes in Computer Science 340. Advances in Petri Nets, Springer-Verlag, pages 249-266.

Koseska-Toszewa, Mazurkiewicz 2010: V. Koseska-Toszewa, A. Mazurkiewicz, Time flow and tenses, SOW, Warszawa.

Koseska-Toszewa, Roszko 2008: V. Koseska-Toszewa, R. Roszko. Remarks on Classification of Parts of Speech and Classifiers in an Electronic Dictionary. In Proceedings of the MONDILEX Open Workshop "Lexicographic Tools and Techniques", Moscow, 3-4 October 2008: 80-88.

Kuryłowicz 1972: J. Kuryłowicz, Miejsce aspektu w systemie koniugacyjnym. In Symbolae polonicae in honorem Stanislai Jodlowski, Wrocław: 93-98.

Maslov 1963: Ju.S. Maslov, Morfologija glagol'nogo vida $v$ sovremennom bolgarskom jazyke, Moskva-Leningrad, page 3.

Mazurkiewicz 1986: A. Mazurkiewicz, Zdarzenia i stany: elementy temporalności, [in:] Studia gramatyczne bułgarsko-polskie, vol. I, Temporalność, Wrocław, pages 7-21.

Penchev 1967: J. Penchev, Kym vyprosa na vremenata v syvremennija bylgarski ezik, Bylgarski ezik XVII, page 134.

Piernikarski 1989: C. Piernikarski, Typy opozycji aspektowych czasownika polskiego na tle słowiańskim, Wrocław, page 10.

Poldauf 1964: I. Poldauf, Podíl mluvnice a nauky o slovníku na problematice slovesného vidu [in:] Studie a práce linguistické (Sborník k šedesátým narozeninám akademika Bohuslava Havránka), Praha, pages 204-205.

Przepiórkowski 2008: A. Przepiórkowski, Powierzchniowe przetwarzanie języka polskiego, Warszawa.

Roszko, D. 2006. Funkcjonalne odpowiedniki litewskiego perfectum w litewskiej gwarze puńskiej $i$ w języku polskim, Warszawa.

Safarewicz 1947: J. Safarewicz, O wyrażaniu dokonaności i niedokonaności w języku łacińskim, Eos 41, 1940-1946, vol. I, 2, page 198.

Saloni 2002: Z. Saloni, Czasownik polski, Wiedza Powszechna, Warszawa.

Satoła-Staśkowiak 2010: J. Satoła-Staśkowiak, Polsko-bułgarskie odpowiedniości przekładowe czasów przeszłych, Instytut Slawistyki PAN, Slawistyczny Ośrodek Wydawniczy, ISBN 978-83-89191-96-0, Warszawa, page 144.

Silić, Pranjković 2005: J. Silić, I. Pranjković Gramatika hrvatskoga jezika za gimnazije i visoka učilišta, Školska Knjiga, Zagreb.

Stankov 1969 : V.Stankov, Bylgarskite glagolni vremena, Sofija. 
Stieber 1973: Z. Stieber, Zarys gramatyki porównawczej języków słowiańskich, Fleksja werbalna, Warszawa, page 9.

Śmiech 1971: W. Śmiech, Funkcje aspektów czasownikowych we współczesnym języku ogólnopolskim, Łódź, pages 5, 6 .

Toporishich 1976: J. Toporišič, Slovenska slovnica, Maribor.

Vuković 1967: J. Vuković, Sintaksa glagola, Sarajevo, pages 276-313. 